\title{
Surviving Research between Two Guns: Lessons Learnt from Nepal
}

\author{
Bhimsen Devkota', $\mathrm{PhD}$ \\ Edwin van Teijlingen ${ }^{2} \mathrm{PhD}$
}

\begin{abstract}
Nepal's decade long violent conflict (1996-2005) between the Nepal Communist Party (Maoist) and the Government of Nepal resulted to over 14000 deaths and thousands others became disabled and lost their properties. During this violent war, the Maoists developed their own health cadres mainly to treat the combatants and the community people under their control areas to some extent. This paper is based on author's personal account of field experiences while conducting $\mathrm{PhD}$ research using mixed methods study comprising in-depth interviews and self-administrated questionnaire on the former Maoist health workers in Nepal. This study suggests a few dilemmas the first author confronted with while undertaking this research. Firstand foremost is the risk involved to both the researcher and the participants in the absence of trustand security on both sides of the conflict. Secondly, the sources of information could easily be biased either deliberately (as propaganda) or more subtly based on respondents' perspectives. The issues of accessing the research participants, relationships, complicity, representation and being rejected by a contact are pertinent issues whencarrying out independent research. Thirdly, maintaining ethics and keeping a right balance between research, humanity and sense of justice is also the dilemma that might have affected the research findings derived from dangerous environments. Fourthly, lack of precise methods that are valid and reliable to investigate certain dynamics of conflict in the politically violent and crisis environment could be equally contested. Fifthly, undertaking crossdisciplinary research on a conflict-related topic during wartime by a researcher with background in allied field is even more challenging. The researcher need to have both an indepth knowledge of conflict theories as well as being able to apply these to another discipline which can be cumbersome. This article presents a personal account of a Rotary fellow who conducted his public health research among the Maoistscombatant health workers of Nepal. Itpresentshis lived experiences thatcould be important in carrying out appropriate and credible research during violent conflict elsewhere in future.
\end{abstract}

Key words: Conflict, health, Maoist, Nepal

\section{Introduction}

Health services research in politically charged and violent environments is neglected (WHO, 2008). Moreover, conducting research on hard-to-reach rebel health workers is particularly challenging, both methodologically and practically (Axnin, WG, Ghimire, D \& Williams NE, 2012; Hoffman, 2003; Kovats-Bernat, 2002; Shah \& Pettigrew, 2009, Sriram et al., 2009). The study was undertaken around 2006 while Nepal was severely engulfed in the home grown Maoist insurgency instigated by the Communist Party of Nepal-Maoist for a decade (1996-

\footnotetext{
I Corresponding Aurhor: Prof. Bhimsen Devkota, PhD, Mahendra Ratna Campus, Tahachal, Kathmandu, Email: devkotabhim@gmail.com

2 Bournemouth University, England, UK
} 
2006). The author was a student of Public Health at the University of Aberdeen in Scotland, UKthough he endeavoured to undertake a conflict research in relation to health services provided by the Maoist rebels in their "base areas" or areas under their control in Nepal. Following participation in a three-month long training at the Rotary Peace Center in Bangkok and further short-term training in the UK and USA, this study was carried out as part of a PhD study. As research fieldwork on a politically charged, revolutionary and violent context(Axninet al., 2012; WHO, 2008) was a challenge; it was no exception for him. The Maoist rebellion was at its height, leading to over 14,000 deaths, destruction of 1,000 health posts, and many government health workers deserting their jobs. About one-third of the health centres in rural Nepal had operated without health workers and people in the remote hills suffered a severe lack of access to health services. On the other hand, the Maoistshad recruited their own health workers to treat their combatants and provide limited services to the communities under their control (Devkotaand van Teijlingen, 2009). In-depth studies of this kind are vital help us understand the key aspect of the conflict, for example without this study the researchers would not know the main motivating factors for joining as rebel health workers, particularly (a) individual reasons; (b) political; and (c) socio-cultural factors (Devkota\& van Teijlingen, 2012). Working with an armed group at such a dangerous and violent context and surviving research was a challenge while it also faced unique problems while doing research in the Nepali context, especially in remote and rural areas. The challenges and paradoxes encountered during the study are outlined below. We trust these insights and our reflections on the fieldwork will be of use to future researchers in similar or related circumstances.

\section{Methods \& Fieldwork Experience}

The study used a mixed-methods design for data collection (MacKenzieBryers, et al. 20I4). Indepth interviews and self-administered questionnaire were used to collect data from the Maoist combatants, while additional interviews were conducted with the government health service providers and policy level authorities (Devkota and van Teijlingen, 20I0;20I2).

This paper is based on the researcher's personal experiences while conducting a research on the former Maoist combatant health workers of Nepal. This is focused on methodological challenges rather than on the study findings

\section{Result and Discussion}

The study on Nepal's Maoist health workers was conducted at a time when the conflict was at its height. It witnessed a number of challenges and dilemmas as follows:

First, as in other studies, this study was confronted with safety and security of both the researchers and the research participants because at that time people were sand-witched between two fires (Devkota \& Teijlingen, 2010). There was absence of trust and security among people. Local people would distrust any new face coming to the village. It was a common apprehension among government security forces, Maoist sympathizers, Maoist forces and ordinary people living in the community. Thus any researcher, as an unknown outsider, would immediately be seen as suspicious. In many visits to the villages, both the Maoists combatants and the government security forces searched and even forced the researchers to 
delete photographs.

Access to research areas and participants was a key issue. Obtaining permission from the Maoist agency to conduct the study, convincing the Maoist rank and file to access the Maoist health workers individually, reaching out to them in a geographically remote and harsh environments, and politically challenging and insecure settings threatened the success of the study. At the time, the researchers' key Maoist contacts kept changing their hideouts, nick names and cell phones in every 2-3 days. When the first researcher finally managed to get someone to agree to be interviewed there were frequent interruptions during these interviews due to security concerns. Similarly, audio-recording interviews and keeping interview records and field-notes were a challenge.

During many visits the government security forces were camouflaged and hidden to search out and destroy the Maoists. They were also disguised to the researchers and presented to the villagers in different ways. Many a time government forces pretended to a Maoist to the researcher intending to find out whether the first researcher belonged to the Maoists side. Both the warring sides would try to find out to whom the researcher belonged. Was he a government agent or a Maoist sympathiser? Often villagers in the community pretended that they did not belong to any side or even know of any side. They wanted to prevent any new persons coming to the village and contacting them. For them, identifying whether the new person was a government spy, a Maoist sympathizer or a member of Maoist army was an issue of life and death. Moreover, ensuring whether the person was a 'genuine' researcher and would not write anything about them personally or anything that could be used against them was really important. However, with hard work from the side of the researcher feeling of mistrust and apprehension used to transform into possible relationship and complicity (Pettigrewet al., 2004).

Whether the methods used for data collection was valid or not was another big issue. Many conflict researchers believe that sources of information could easily be biased either deliberately (as propaganda at the time) or subtly based on respondents' perspectives and sympathies. In addition, there was lack of precise methods and tools valid and reliable to investigate in politically violent and crisis environments. The quality and reliability of data collected in conflict zone is thus a subject of substantial controversy. The researchers, therefore, rather than relying on one method, used a mixed-methods approach, which contributed substantially to understanding of the rebel health services in Nepal. The research used simultaneous mixed methods with flexibility in research methods, used snowball sampling (Macrae, et al., 1996), for identifying the Maoist health workers in the communities -starting with selected contacts who were available but reluctant to disclose their identity. The research employed 'theoretical sampling' (Glaser \& Strauss, 1967) where interviews were continued until the findings reached saturation. The research participants were selected from Maoist and non-Maoist sources for collecting reliable data and to perform triangulation of the findings (Keenan Forrest et al. 2005). 
The use of mixed methods approach allowed for triangulation of methods from both the Maoist and non-Maoist sources and use of systematic analysis of the data (SPSS 16 for quantitative and NVivo version 7 and framework analyses for qualitative data) and helped analyse the data systematically. The research was conceptualized near the end of the armed conflict and the data were collected immediately after the peace agreement. It had many implications on this study. There was a situation of confusion because of the transition of the Maoists from being strictly underground to a more open environment whilst still keeping their underground mechanisms operational. The study might have been influenced by the 'veracity effect' (Sriram et al., 2009; Weinstein, 2007). The researchers observed a shift in perspectives of the Maoists vis-à-vis winning or losing the war to a more victorious situation and atmosphere. Therefore, they conducted a few additional interviews after the peace process for data verification as access to the hard-to-reach rebel health workers was easier during the post negotiation period.

The researchers used the privilege of his academic position at a UK university and native residency in a conflict-affected district (i.e. Gorkha district) and strictly adhered to neutrality, research ethics and academic integrity. Maintaining ethics and keeping a right balance between research, humanity and sense of justice was central during the study. Balancing scholarly objectivity and integrity with researchers personal affinities or relationships did work well. The researcher was guided with a desire for peace rather than with a sense of justice. These measures helped address key methodological issues mentioned above.

Finally, there were some researcher related individual factors. Undertaking a cross-disciplinary research on a conflict-related topic with limited knowledge of conflict theories in a violent context by a researcher having background in an allied field(i.e. public health) was challenging. The researcher's Rotary Fellowship for three months as well as to other short-term training sessions and workshops on peace and conflict research helped address most of these issues. The issues of 'outsider or insider', and 'us and them' was pertinent as it was a determining factor whether or not the first researcher was allowed access to and the chance to interview Maoist health workers. In one instance, the insurgents asked for a donation or favour to their movement, which put the researcher in a difficult position. In many interviews, the researcher had to deal with emotional situations while hearing stories of the war. The first researcher's long academic teaching experience, both in a highly conflict affected district (Gorkha) and at Tribhuvan University in Kathmandu and Aberdeen University of the UK, helped establish trust and relationships with both the sides.

The study obtained ethical approval from the Nepal Health Research Council (NHRC) and the Health Division of the UCPN-M and All Nepal Public Health Worker's Association (ANPHWA)- Maoist sister wing, granted access to their health workers (Devkota and van Teijlingen 2010). Letters from the NHRC, the University of Aberdeen, Tribhuvan University, and All Nepal Public Health Workers' Association helped create a favourable environment for accessing the research participants. However, the researcher had to be prompt and careful in presenting the right kind of letter to the right person. The researcher maintained political neutrality and kept a low profile in terms of clothing, eating, conversation and mannerisms and spoke the local Nepali language. The researcher ensured privacy/confidentiality of interviews, 
anonymity and confidentiality of identity and information that was collected. In line with good research practice, participants were given the option to not participate or stop the interview any time they wanted.

\section{Conclusion}

The first researcher experienced many security, privacy, logistical and methodological challenges in course of this field data collection. The study was done in a volatile and violent context. The researcher used a number of measures to address the problems, challenges and dilemmas encountered to enhance the quality of the data and analysis. We argue that there is often no quick fix and that the researcher has to keep every option flexible whilst maintaining well-developed scientific approaches to reduce bias as much as possible. Moreover, the researcher should take into account of "Do No Harm" principle while working between two violent armed forces. It is recommended that methods and tools for conducting research in difficult and violent circumstances be developed and disseminated by the academic institutions and institutions working in the field of peace building.

\section{Acknowledgments}

We would like to thank all the research participants who gave their valuable time for our study.

\section{References}

Axnin, WG, Ghimire, D. \& Williams, NE(20I2). Collecting survey data during armed conflict. J Off Stat. 28(2): 153-171.

Devkota, B. \& van Teijlingen E. (2009) Politicians in Apron: Case study of Rebel Health Services in Nepal, Asia-PacJ Public Health 2 I (4): 377-384.

Devkota, B. \& van Teijlingen E. (2010) Demystifying the Maoist barefoot doctors of Nepal, Med Conflict Survival26: 108-123.

Devkota, B. \& van Teijlingen, E. (20I2) "Why did they join?" Exploring the motivation of rebel health workers in Nepal J Conflictology 3(I): 18-29.

Glaser, B. \& Strauss, A.L. (1967). The discovery of grounded theory: Strategies for qualitative research. Chicago, Aldine.

Hoffman, D. (2003). Frontline anthropology: Research in time of war. Anthropol Today, 19(3): $9-12$.

Forrest Keenan, K., van Teijlingen, E. \& Pitchforth, E. (2005) The analysis of qualitative research data in family planning and reproductive health care, J Fam Plann Reprod Health Care 3I (I): 40-43.

Kovats-Bernat, J.C.(2002). Negotiating dangerous fields: Pragmatic strategies for fieldwork amid violence and terror. Am Anthropol, 104(I): 208-222.

MacKenzie Bryers, H., van Teijlingen, E. \& Pitchforth, E. (2014) Advocating mixed-methods approaches in health research, Nepal J Epidemiol 4(5): 4I7-422. 
Macrae, J., Zwi A.B \& Gilson, L. (1996). A triple burden for health sector reform: post-conflict rehabilitation in Uganda. Soc Sci Med 42 (7): 1095-I 108.

Pettigrew, J Shneiderman, S. \& Harper, I. (2004). Relationships, complicity and representation: Conducting research in Nepal during the Maoist insurgency. Anthropol Today, 20(I): 2025.

Shah, A.\& Pettigrew, J. (2009). Windows into a revolution: Ethnographies of Maoism in South Asia. Dialect Anthropol 33:225-25I.

Shneiderman, S, \& Turin, M. (2004). The Path to Janasarkar in Dolakha District: Towards ethnography of the Maoist movement in Himalayan People's War: Nepal's Maoist Rebellion. Michael Hutt, (ed.). London: Hurst \& Co.: 77-109.

Sriram, C.L. King, J.C, Mertus, J.A. Ortega, O.M,\& Herman, J. (2009).Surviving field research: Working in violent and difficult situations. London: Routledge.

Weinstein, J. M. (2007).Inside Rebellion: The politics of insurgent violence, Cambridge University Press.

WHO (2008). Neglected health system research: Health policy and systems research in conflictaffected fragile states. Research Issue Oct 2008. Retrieved from

http://digicollection.org/hss/documents/5I5873e.pdf 